\title{
POPULATION DYNAMIC OF ENDEAVOUR SHRIMP (Metapenaeus elegans) IN THE WATERS OF SOUTH COAST OF JAVA
}

\author{
Ali Suman'), Budi Iskandar Prisantoso1), and Gatut Bintoro ${ }^{2)}$ \\ 1) Research Center for Capture Fisheries, Ancol-Jakarta \\ 2) Politani Perikanan, Pangkep, Sulawesi Selatan \\ Received March 21-2005; Received in revised from Sept. 7-2005; Accepted Dec. 14-2005
}

\begin{abstract}
Study on the population dynamic of endeavour shrimp ( $M$. elegans) was conducted in the south coast of Java based on data collected during a period of November 2002 to October 2003. The purpose of the study is to identify biological and population parameters of the endeavour shrimp. Results shows that the size at firts maturity of endeavor shrimp was $32.6 \mathrm{~mm}$ in carapace length. Sex ratio of males and females was 1.0:1.7. The chi square test indicated that comparison of male and female of the endeavour shrimp was significantly different. It means that there was imbalance in number between males and females. A number of 554 females were examined, resulting $60 \%$ were immature, and $40 \%$ were mature. The spawning season of endeavour shrimp in south coast of Java occurs throughout the year with two peaks, January (north west monsoon) and August (south east monsoon). The growth parameter of endeavour shrimp was 1.5 per year with maximum carapace length $\left(\mathrm{L}_{\mathrm{oo}}\right)$ of $51.5 \mathrm{~mm}$. Instantenous total mortality $(\mathrm{Z})$ and natural mortality $(\mathrm{M})$ rates were 4.53 and 1.15 per year, respectively. While the respective fishing mortality $(F)$ and exploitation rate $(E)$ were 3.38 and 0.75 per year time respectively to mointain the sustainability of this shrimp fisheries resources. The exploitation rate of endeavour shrimp in south coast of Java was high. This suggests that fishing effort of the endeavour shrimp in that waters should be reduced.
\end{abstract}

KEYWORDS: $\quad$ shrimp, south coast of Java, population dynamic

\section{INTRODUCTION}

Endeavour shrimp ( $M$. elegans) is one of penaeid shrimp species, dominantly caught in the waters of south coast of Java. Catch of endeavour shrimp may reach the third highest after others small size shrimp (Parapenaeopsis stylifera) and brown shrimp (Metapenaeus ensis) (Suman, 2004).

Exploitation of the endeavour shrimp in the water of south coast of Java has been carried out for years (Van Zalinge \& Naamin, 1975) and become more intensive in the recent years due to an increase of local and or foreign market demand. If this situation continues to occur, sustainability of the shrimp stock would be disturbed in the future. Therefore comprehensive research is needed to reach rational utilization in order to maintain sustainability of the stock for prosperity purposes in the future (Naamin et al., 1992).

This paper discussed population dynamic of the endeavour shrimp ( $M$. elegans) in the south coast of Java. It hopes that the result can be used as basic and important information for other endeavour shrimp studies and sustainable exploitation of the endeavour shrimp in the waters of the south coast of Java.

\section{MATERIALS AND METHODS}

Samples of the endeavour shrimp were taken from field research in south coast waters of Java (Figure 1) from November 2002 to October 2003. Biometric studies (carapace length, sex, and gonad maturity identifications) were done for 872 samples. Spearman \& Karber method (Udupa, 1986) was applied to identify the size at first maturity with assumption that average size of first maturity occurs when $50 \%$ of the endeavour shrimp is already mature. Logarithmic size of the first sex mature $(m)$ was calculated based on equation below:

$$
m=x k+X / 2-(X \Sigma p i)
$$

where:

$$
\begin{aligned}
& m=\text { logarithmic size of first sex mature } \\
& \mathrm{xk}=\text { logarithmic size of mean value of } 100 \% \text { mature } \\
& \mathrm{X}=\text { logarithmic different of mean value } \\
& \mathrm{pi}=\text { comparison of sex maturity of each length class }
\end{aligned}
$$




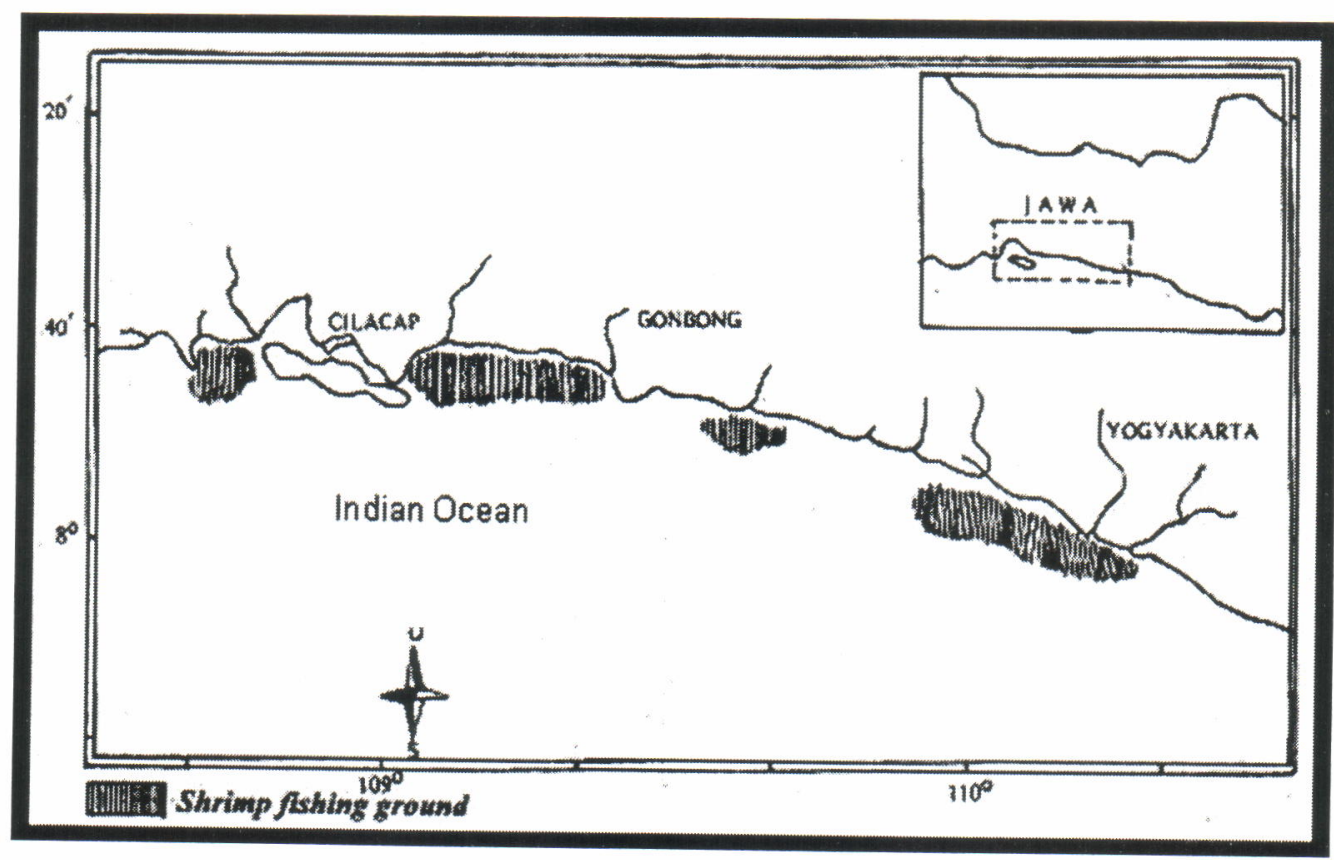

Figure 1.

Shrimp fishing ground in the waters of south coast of Java.

In this classification, gonad maturity (stage) I and II are classified as immature while stage III, IV, and V are mature. The morphologically identified sex maturity stages of the shrimp (Tuma, 1967 in Naamin, 1984) are as follows $\mathrm{I}=$ quiescent or undeveloped; $\|$ = developing; $\mathrm{III}=$ early maturity; IV = ripe; and $\mathrm{V}=$ spent. While chi square method was used to identify sex comparison (Sudjana, 1975).

Growth rate $(\mathrm{K})$ and maximum carapace length $\left(\mathrm{L}_{\circ o}\right)$ were analysed by tracing the modes of monthly carapace length distribution using ELEFAN program (Sparre \& Venema, 1992; Gayanilo et al., 1993). Total mortality $(Z)$ was calculated from catch curve (Sparre \& Venema, 1992; Gayanilo et al., 1993) and natural mortality (M) was predicted using combination of Pauly empirical equation (Pauly, 1985) and fishing mortality rate $(F)=Z$ $M$, while exploitation rate $(E)=F / Z$ (Sparre \& Venema, 1992).

Table 1.

\section{RESULTS AND DISCUSSIONS}

\section{Size at First Maturity}

Shrimp age and size at first maturity are important for management purposes.

The size at first maturity of endeavour shrimp in the waters of south coast of Java was $32.6 \mathrm{~mm}$ in carapace length with confidence limits of 31.8 to $33.8 \mathrm{~mm}$. Martosubroto (1978) reported that $M$. ensis in Tanjung Krawang waters reached first maturity when they grow to about $20 \mathrm{~mm}$ in carapace length. This difference in reaching first maturity might be influenced by the availability of food and environment condition such as temperature and salinity.

Maturity percentage frequencies distribution of the endeavour shrimp female can be seen in Table 1. Table 1 also illustrated that the longer the size of carapace length, the higher the maturity percentage of shrimp.

\begin{tabular}{cccc}
\hline Carapace length $(\mathbf{m m})$ & Percentage $(\%)$ & Carapace length $(\mathbf{m m})$ & Percentage $(\%)$ \\
\hline 24 & 3 & 36 & 60 \\
26 & 18 & 38 & 76 \\
28 & 22 & 40 & 78 \\
30 & 37 & 42 & 88 \\
32 & 41 & 44 & 100 \\
34 & 51 & & \\
\hline
\end{tabular}




\section{Sex Ratio}

Data on sex and maturity of fish or shrimp stock are important as basic information for reproduction biology of the stock (Suhendrata \& Merta, 1986). Homogenity test informs that value of male and female was imbalance, it was also identified that sex ratio of the endeavour shrimp in south coast waters of Java was found to be 1.0:1.7. This ratio is significantly different with those reported in previous researchs (Suman et al., 1987; Suman, 1991). That first authors found the value of 1.0:1.2 in Pangandaran waters, while the later found 1.0:2.5 in Kotabaru waters (South Kalimantan).

The measured carapace length of 318 male of endeavour shrimp ranged from 20 to $40 \mathrm{~mm}$ and of 554 female ranged from 20 to $44 \mathrm{~mm}$. Suman et al. (1987) illustrated that in Pangandaran waters, range of carapace length of male endeavour shrimp was 12.2 to $24.3 \mathrm{~mm}$ and of female was 13.3 to $31.9 \mathrm{~mm}$. Meanwhile in Kotabaru, South Kalimantan, it were found that carapace length of male and female endeavour shrimp ranged from 21.2 to $32.6 \mathrm{~mm}$ (Suman, 1991).

This data informs that range of carapace length of female was higher than that of male. This phenomenon might be influenced by difference in growth type of female and male. The growth of female was faster than male so that carapace length of female was always longer than male in the same age (Naamin, 1984).

\section{Spawning Season}

Spawning season of shrimp in a certain waters can be studied by identifying distribution of egg density or shrimp maturity in that waters (Martosubroto, 1978).

The observation shows that the number of immature and mature female endeavour shrimp were $331(60 \%)$ and $223(40 \%)$, respectively. It could be concluded that number of immature endeavour shrimp was higher than mature endeavour shrimp. It mean that on the biological aspects, status of the shrimp stock was likely in danger zone because fishing activity exploited more young shrimp than adult shrimp.

The distribution frequency of female endeavour shrimp in two maturity stages from November 2002 to October 2003 can be seen in Table 2.

Table 2 shows that the highest number of mature female shrimp occurred in January and August. It shows that peaks of spawning seasons of endeavour shrimp in the waters south coast of Java took place twice, in January and August. In Tanjung Krawang waters, peak of spawning season of endeavour shrimp occurred in March and December (Martosubroto, 1978) while in Kotabaru waters, South Kalimantan, peak of spawning season occurred happened in June only (Suman, 1991).

Table 2. Frequency distribution of gonad maturity of female endeavour shrimp in the waters of south coast of Java

\begin{tabular}{cccc}
\hline \multirow{2}{*}{ Year } & Month & \multicolumn{2}{c}{ Maturity stage (\%) } \\
\cline { 3 - 4 } 2002 & November & Immature & Mature \\
\hline \multirow{2}{*}{2003} & December & 85 & 15 \\
& January & 53 & 47 \\
& February & 47 & 53 \\
& March & 94 & 6 \\
& April & 65 & 35 \\
& May & 65 & 35 \\
& June & 50 & 50 \\
& July & 70 & 30 \\
& August & 51 & 49 \\
& September & 44 & 56 \\
& October & 53 & 47 \\
\end{tabular}




\section{Growth Parameter}

Basically, ELEFAN program is applied to interprete carapace length in time series data adjusted with von Bertalanffy growth curve. Growth pattern is indicated by curve which crosses highest number of modes (Sparre \& Venema, 1992).

Values of growth rate $(K)$ and maximum carapace length $\left(L_{\circ o}\right)$ were recorded by identifying monthly the carapace length frequency (Figure 2). The value $1.5 \mathrm{per}$ year and $51.5 \mathrm{~mm}$, were respectively for $K$ and $L_{o o}$.

Value of $K$ and $L$. was greater than 1 , showing that growth type of endeavour shrimp in the south coast waters of Java was fast growth (Sparre \& Venema). Eventhough care must be taken into account when planning the amount of effort allowed to be applied each year for exploiting the shrimp stock in order to obtain rational management of the stock. If value of recommended effort was lower, uncapture shrimp stock would be useless or number of natural mortality would be high because the growth type of the stock was fast. It means that the stock had short life span. In contrast, if value of recommended effort was higher, the stock would be disturbed or even jeopardized because there was not enough time for population to grow the recruitment number and amount of next year stock will decrease.

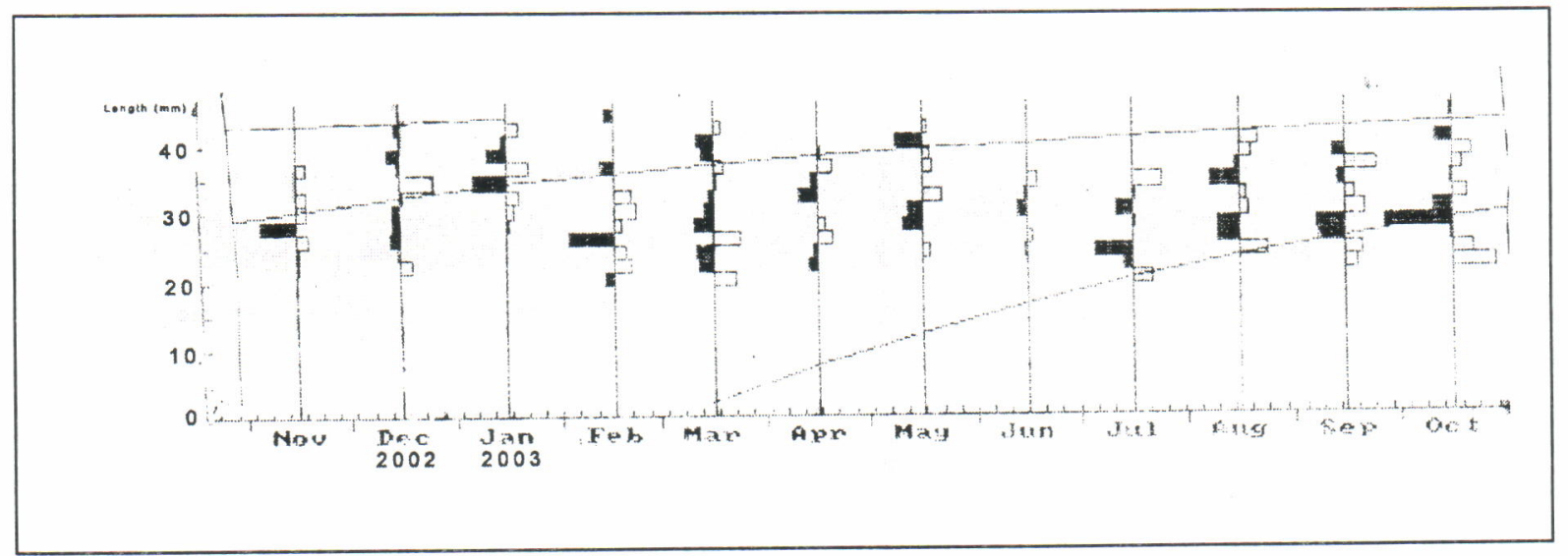

Figure 2.

Carapace length distribution of endeavour shrimp (M. elegans) and growth curves fitted by ELEFAN.

\section{Mortality Rate and Exploitation Rate}

Value of total mortality $(Z)$ represented by value of slope (b) between Ln N/t and relative age (Figure 3 ) was 4.53 per year. Meanwhile value of natural mortality (M) and fishing mortality (F) were 1.15 per year and 3.38 year, respectively.

Pauly et al. (1984) reported that values of $Z$ and $F$ of Indian shrimp (Metapenaeus affinis) in Versoba waters, were 5.29 and 3.0 per year respectively. While values of $Z$ and $F$ of Metapenaeus kutchensis were 5.83 and 2.20 per year, respectively. It was also reported that the differences in value of shrimp mortality rates in several waters were caused by different level of effort, predator, and environmental conditions.

By using the exploitation rate equation $(E)=F / Z$, it obtained that the value $E$ of endeavour shrimp in the waters of the south coast of Java was 0.75 per year. Based on Pauly criterion (Pauly et al., 1984), it concluds that over fishing of the shrimp stock occurred in this location waters of Java, because rational the fishing of fish or shrimp stock can be gained if the value $E$ in that waters equals 0.5 . If the value $E$ is more than 0.5 , the stock would endangered thus effort has to be decreased in order to sustain the stock. Phenomenon of the endeavour shrimp stock in the south coast waters of Java suggests that fishing effort of the endeavour shrimp stock should be deducted until $50 \%$ of the present status.

\section{CONCLUSION AND RECOMMENDATION}

1. The endeavour shrimp ( $M$. elegans) reached at for maturity at the carapace length of $32.4 \mathrm{~mm}$.

2. Sex ratio of male and female of endeavour shrimp (M. elegans) was 1.0:1.7. It called in imbalance condition.

3. Spawning season of endeavour shrimp (M. elegans) occured throughout the year with two peaks in January (west monsoon) and August (east monsoon). 


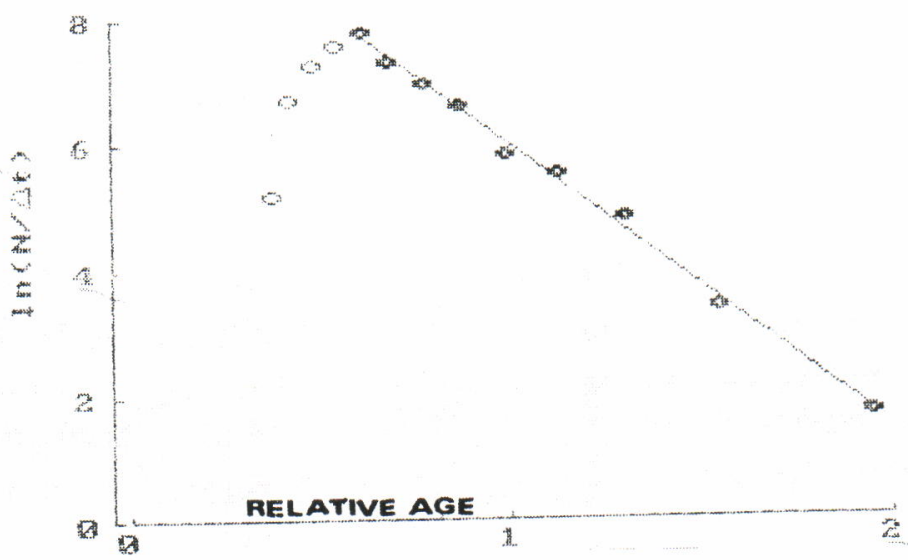

Figure 3. The value of total mortality $(Z)$ of endeavour shrimp (M. elegans) in south coast waters of Java.

4. Values of growth rate $(\mathrm{K})$ and maximum carapace length $\left(L_{\text {. }}\right)$ of endeavour shrimp (M. elegans) in the south coast waters of Java were 1.5 per year and $51.5 \mathrm{~mm}$, respectively.

5. Values of total mortality $(Z)$, natural mortality $(M)$, and fishing mortality $(F)$ of endeavour shrimp ( $M$. elegans) were $4.53 ; 1.15$; and 3.38 per year respectively.

6. Exploitation rate $(E)$ of endeavour shrimp stock in south coast waters of Java was quite high; 0.75 per year.

7. In order to keep sustainability of endeavour shrimp stock, it suggests biologically that fishing effort should be deducted until $50 \%$ of present status.

8. In order to perform sustainability management of the endeavour shrimp ( $M$. elegans) stock, comprehensive research in biology, economic, and social aspects are recessary to be conducted.

\section{Acknowledgements:}

This paper is the result of: The Research on Stock of Demersal Fish in Indian Ocean 2002-2003

\section{REFERENCES}

Gayanilo, F. C. Jr. P. Sparre, \& D. Pauly. 1993. The FISAT user's guide. FAO computerized information series fisheries. ICLARM-DIFMAR.
Martosubroto, P. 1978. Musim pemijahan dan pertumbuhan udang jerbung (Penaeus merguiensis de Man) dan udang dogol (Metapenaeus ensis de Haan) di perairan Tanjung Krawang. Prosiding Seminar II Perikanan Uo'ang. Hal.7-20.

Naamin, N. 1984. Dinamika populasi udang jerbung (Penaeus merguiensis de Man) di perairan Arafura dan alternatif pengelolaannya. Disertasi Doktor pada Fakultas Pasca Sarjana. Institut Pertanian Bogor. Bogor. 381 hal.

Naamin, N., B. Sumiono, S. llyas, D. Nugroho, B. Iskandar P. S., H. R. Barus, M. Badrudin, A. Suman, \& E. M. Amin. 1992. Pedoman teknis pemanfaatan dan pengelolaan sumber daya udang penaeid bagi pembangunan perikanan. Seri Pengembangan Penelitian Perikanan No.PHP/KAN/PT/22/1992. Badan Penelitian dan Pengembangan Pertanian. 86 hal.

Pauly, D., J. Ingles, \& R. Neal. 1984. Application to shrimp stocks of objective methods for the estimation of growth, mortality, and recruitment related parameters from length frequency data (ELEFAN I and II). In Penaeid shrimp-their biology and management. 220-234. Fishing News Book Limited. Farnham-Surrey-England.

Pauly, D. 1985. Some simple method for the assesment fish stock. FAO Fish. Tech. Paper (234). Rome. 
Sparre, P. \& S. C. Venema. 1992. Introduction to tropical fish stock assesment. Part I. Manual. FAO Fish. Tech. Pap. No.306/1.

Sudjana. 1975. Metode statistika. Penerbit Tarsito. Bandung.

Suhendrata, T. \& I. G. S. Merta. 1986. Hubungan panjang berat, tingkat kematangan gonad, dan fekunditas ikan cakalang, Katsuwonis pelamis (Linnaeus) di perairan Sorong. Jurnal Penelitian Perikanan Laut. No.34. 11-19.

Suman, A., B. Sumiono, \& M. Rijal. 1987. Perikanan jaring mogol di daerah Pangandaran, Jawa Barat. Jurnal Penelitian Perikanan Laut. No.43. 89-98.
Suman, A. 1991. Status perikanan udang di perairan Kotabaru, Kalimantan Selatan. Prosiding Temu Karya IImiah Perikanan Rakyat. Hal. 22-32.

Suman, A. 2004. Pola pemanfaatan sumber daya udang dogol (Metapenaeus ensis de Haan) secara berkelanjutan di perairan Cilacap dan sekitarnya. Disertasi Doktor pada Sekolah Pascasarjana. Institut Pertanian Bogor. Bogor.

Udupa, K. S. 1986. Statistical method of estimating the size at first maturity in fishes. Fishbyte 4 (2). 8-10. ICLARM. Metro Manila.

Van Zalinge, N. P. \& N. Naamin. 1975. The Cilacap based trawl fishery for shrimp along the south coast of Java. Laporan Penelitian Perikanan Laut. No.2. $1-15$. 